Article

\title{
When Populist Leaders Govern: Conceptualising Populism in Policy Making
}

\author{
Attila Bartha ${ }^{1,2, *}$, Zsolt Boda ${ }^{1}$ and Dorottya Szikra ${ }^{1}$ \\ ${ }^{1}$ Centre for Social Sciences, Hungarian Academy of Sciences Centre of Excellence, H-1097 Budapest, Hungary; E-Mails: \\ bartha.attila@tk.mta.hu (A.B.), boda.zsolt@tk.mta.hu, (Z.B.), szikra.dorottya@tk.mta.hu (D.S.) \\ 2 Department of Public Policy, Corvinus University of Budapest, 1093 Budapest, Hungary \\ * Corresponding author
}

Submitted: 15 February 2020 | Accepted: 5 May 2020 | Published: 17 July 2020

\begin{abstract}
The rise of populist governance throughout the world offers a novel opportunity to study the way in which populist leaders and parties rule. This article conceptualises populist policy making by theoretically addressing the substantive and discursive components of populist policies and the decision-making processes of populist governments. It first reconstructs the implicit ideal type of policy making in liberal democracies based on the mainstream governance and policy making scholarship. Then, taking stock of the recent populism literature, the article elaborates an ideal type of populist policy making along the dimensions of content, procedures and discourses. As an empirical illustration we apply a qualitative congruence analysis to assess the conformity of a genuine case of populist governance, social policy in post-2010 Hungary with the populist policy making ideal type. Concerning the policy content, the article argues that policy heterodoxy, strong willingness to adopt paradigmatic reforms and an excessive responsiveness to majoritarian preferences are distinguishing features of any type of populist policies. Regarding the procedural features populist leaders tend to downplay the role of technocratic expertise, sideline veto-players and implement fast and unpredictable policy changes. Discursively, populist leaders tend to extensively use crisis frames and discursive governance instruments in a Manichean language and a saliently emotional manner that reinforces polarisation in policy positions. Finally, the article suggests that policy making patterns in Hungarian social policy between 2010 and 2018 have been largely congruent with the ideal type of populist policy making.
\end{abstract}

\section{Keywords}

congruence; Hungary; policy making; political parties; populism; social policy

\section{Issue}

This article is part of the issue "Populism and Polarization: A Dual Threat to Europe's Liberal Democracies?" edited by Jonas Linde (University of Bergen, Norway), Marlene Mauk (GESIS - Leibniz Institute for the Social Sciences, Germany) and Heidi Schulze (GESIS-Leibniz Institute for the Social Sciences, Germany).

(C) 2020 by the authors; licensee Cogitatio (Lisbon, Portugal). This article is licensed under a Creative Commons Attribution 4.0 International License (CC BY).

\section{Introduction}

The policy aspects of populism and their relation to polarising policy practices have largely been neglected in populism studies. Since the seminal article of Mudde (2004) on to the emergence of a populist Zeitgeist in Western Europe, the scholarship of populism research has focused on political actors and discourses of populism and particular attention was devoted to the ambiguous relationship between populism and liberal democ- racy (Canovan, 1999; Jagers \& Walgrave, 2007; Mudde \& Rovira Kaltwasser, 2012). The lack of attention to the realworld consequences of populist governance is all the more striking in that in the past decade, populist parties have come into governing positions in several European countries and in the Americas (Hawkins \& Littvay, 2019). Policy reforms that were adopted by populist governments may have tangible impact on social and political polarisation although this effect is yet to be explored. The fact that populist parties and leaders are in power 
thus offers a novel opportunity to study the practice of their governance and policy making. In this respect, the case of Central and Eastern Europe seems particularly relevant as "in these countries, populism, if anything, is even more widespread" (Kriesi, 2014, p. 372) than in Western Europe.

Accordingly, our research has the ambition to conceptualise the specific features of populist policy making and to suggest a way in which to study this phenomenon. To this aim we theoretically address three core elements of policy making: the substantive (the content), the procedural and the discursive patterns of populist policies. The article is structured as follows: After presenting the analytical framework and the methodology of the research (Section 2) we reconstruct the implicit ideal type of policy making in liberal democracies (Section 3). Then we elaborate an ideal type of populist policy making (Section 4). Finally, we apply a congruence analysis to qualitatively assess the conformity of our ideal type of populist policy making with a typical case of populist governance, that of Hungarian social policy between 2010 and 2018 (Section 5). Here, we do not make a solid, stepby-step case study analysis in a particular social policy area, but we adopt empirical findings of earlier studies exemplifying the use of our ideal type in empirical research. In the concluding part we discuss the implications of populist policy making on the polarisation of societies and the future of liberal democracies.

\section{Analytical Framework and Methodology}

As our theoretical aspiration is to conceptualise the relevant features of populism in policy making, we use the Weberian ideal type framework. Recent theoretical and methodological discussions (Rosenberg, 2016) have provided new inspirations to apply the ideal type framework in empirical policy studies (Peters \& Pierre, 2016). Following this agenda, we construct sociological ideal types (we refer to them henceforward simply as ideal types). In our case this means that both the substantive and the discursive components are constitutive elements of the policy making ideal types, while the context of social relationships is reflected through the procedural components.

We use the method of congruence analysis (Blatter \& Haverland, 2012) to investigate the empirical relevance of our ideal type of populist policy making. Accordingly, we qualitatively assess the congruence of an assumed typical case, Hungarian social policy between 2010 and 2018 with theoretical expectations deduced from the ideal type. Post-2010 Hungary is a genuine case of populist governance (Batory, 2016; Jenne \& Mudde, 2012) and social policy is a particularly suitable area to study populist policy making as populist leaders tend to reframe social policy measures to build their power regime (Ketola \& Nordensvard, 2018). Welfare policy outcomes directly affect the majority of people, thus playing a crucial role in boosting majoritarian support of the elec- torate. In addition, welfare reforms may have a profound effect on social and political polarisation that in turn enhances citizens' propensity to populism.

Welfare state reforms, including pensions, taxation, unemployment and family policies reflect government ideas about national solidarity and mechanisms of inclusion and exclusion. At the same time, they have a central importance in communicating the position of the ruling elite about gender and families (Béland, 2009; Morgan, 2013). Besides utilising earlier research on Hungarian welfare state reforms after 2010, we also used the legislative and policy documents (bills, laws, and the Prime Minister's assertions) available in the database of the Hungarian Comparative Agendas Project (Boda \& Sebők, 2019). Having identified major welfare state changes between 2010 and 2018 we qualitatively assess the dominant substantive, procedural and discursive elements of social policy making in Hungary. This way we combine the positivist institutional analysis perspective of policy decisions with a post-positivist discursive approach (Schmidt, 2008). It is important to note that methodologically the qualitative assessment of the major policy changes does not have an aspiration that we expect from classical explorative case studies; the applied logic of case selection and the empirical reconstruction of the typical policy patterns supported by area specific policy expertise of the researchers, however, fits the qualitative congruence analysis research design and the conceptual ambitions of the study.

\section{Conceptual Departure: The Liberal Democratic Model of Policy Making}

Governance and policy making varies between countries and across time: A variety of actors and institutions participates in the delivery of governance functions and their configurations delineate different governance models (Peters \& Pierre, 2016). However, we argue that beyond the variations of governance types the ideal type of policy making in liberal democracies is implicitly applied.

One tacit assumption of policy making models in liberal democracies is that a relatively coherent system of ideas shapes policy positions: Ideas play a key role in the policy content and "can explain crucial aspects of policy development" (Béland, 2009, p. 704). At the same time, although majoritarian preferences have a pivotal role, they are substantively constrained by the protection of minority rights. In addition, policy content is heavily influenced by area-specific technocratic expertise (Weible, 2008) and mainstream policy paradigms that tend to create policy monopolies (Baumgartner, Berry, Hojnacki, Leech, \& Kimball, 2009). As a result, the content of policies is mostly stable and policy changes are mainly incremental.

A main procedural feature of policy making in liberal democracies is institutionalism: The policy process is constrained and channelled by formal and informal institutions, thus political leaders have a low level of discretion 
(Przeworski, Stokes, Stokes, \& Manin, 1999). The constitutional embeddedness of pluralism limits the majoritarian logic as pluralism acknowledges the role of different social and political actors throughout the policy cycle (Baumgartner et al., 2009). This implies that public discussions inform the electorate on proposed policy alternatives. In discursive terms rival policies in this policy making model are interpreted through competing discourses and policy frames by manifold stakeholders. Policy discourses with high and positive valence (Cox \& Béland, 2013) are generally applied. At the same time, the role of discursive governance (Korkut, Mahendran, Bucken-Knapp, \& Cox, 2015) is limited: Although strategic metaphors are typically used in government discourses, public policy problems are usually conceptualised with specific policy language terms.

We use the ideal type of policy making in liberal democracies (see Table 1) as an anchor, a potential antithesis of the populist policy making ideal type. Populist policy making, however, is not necessarily a fully divergent, alternative model leaning towards illiberal governance (Pappas, 2014). Indeed, populist policy making might appear within liberal democracies; similar to the 'étatiste' model of governance that can operate either in authoritarian or in democratic political regime contexts (Peters \& Pierre, 2016, pp. 91-92).

\section{Populist Policy Making: Constructing an Ideal Type}

Populism is a particularly precarious conceptual edifice in contemporary political science (Aslanidis, 2016) and encompasses three competing understandings. One approach interprets populism as a political logic "through which a personalistic leader seeks or exercises government power based on direct, unmediated, uninstitutionalized support from large numbers of mostly unorganized followers" (Weyland, 2001, p. 14). Another group of scholars considers populism as a political communication style (Knight, 1998) characterised by a Manichean logic ('elite' vs. 'people') and adversarial narratives as well as the depiction of crises that imply the need for immediate government intervention. The third main perspective, the ideational approach conceptualises populism as a thin-centred ideology that considers society to be ultimately separated into two homogeneous and antagonistic groups, 'the pure people' and 'the corrupt elite,' and which argues that politics should be an expression of 'the volonté générale of the people' (Mudde, 2004; Mudde \& Rovira Kaltwasser, 2012). Accordingly, populism fundamentally opposes both elitism and pluralism (Mudde, 2004).

The umbrella term of populism suggested by Pappas (2014) provides an appropriate theoretical framework for our research. He focuses on majoritarian political logic and polarising narratives, encompassing thus the discursive framing as well as the procedural features of populism in policy making. We enrich this perspective with Weyland's idea (2001) on personalistic leadership and the unmediated contact between the political leaders and the electorate.

\subsection{Populist Policies: A Substantive View}

Although left-wing and right-wing populists have divergent visions about 'good society,' they also have some policy preferences in common. In foreign policy, they take a critical stance towards supranational institutions, advocate the primacy of nation states and reject liberal globalisation. In economic policy, populists tend to blame, and when in power, punish the unpopular banking elite (O'Malley \& FitzGibbon, 2015) and transnational companies (Bartha, 2017). Some typically assumed populist policy positions, however, derive from intermingling populism with nationalism (De Cleen, 2017). Law-and-order punitive measures in criminal justice policy, negation of extending LGBTQ rights (Pappas, Mendez, \& Herrick, 2009) or perceiving gender equality as jeopardising the idea of the traditional family (Korkut \& EslenZiya, 2011; Szikra, 2019) can be deduced from right-wing nationalism of the respective political parties and not from their populism.

As populism travels across ideologies, the assumed common substantive components of populist policies are malleable and transient. While part of the European scholarship conflates the thin ideology of populism with thick right-wing nativism (Wodak, 2015), in Latin America as well as in Mediterranean Europe a left-wing, inclusionary type of populism has developed (Stavrakakis \&

Table 1. Ideal type of policy making in liberal democracies.

Policy content

Policy process

Policy discourse
Policy embedded into a relatively coherent system of ideas

Central role of mainstream policy paradigms supported by area-specific policy expertise Majoritarian policy preferences constrained by the protection of minority rights Incremental policy changes dominate

Constrained by formal and informal institutions

Plurality of participating actors in each stage of the policy process

Public discussion on proposed policy alternatives

Limited use of discursive governance

Competing discourses and policy frames

Dominant policy discourses with high and mainly positive valence 
Katsambekis, 2014). Empirical observations confirm that the marriage of populism with nativism and the subsequent ethnic polarisation is not necessary, but contingent. Taggart denotes "the empty heart of populism" as a reflection of the lack of core values that implies its essentially 'chameleonic' nature (Taggart, 2004, p. 275). The Muddean thin ideology approach also admits the substantive flexibility of populism implying a wide array of populist policy measures (Mudde, 2004).

Though policy contents advocated by right-wing and left-wing populists may differ fundamentally, certain common features of populist policies can be theoretically detected. Populist leaders are particularly responsive to the majoritarian preferences of their electorate (Urbinati, 2017). Accordingly, populist policy measures tend to harm minority interests, and they are hostile towards unpopular minorities (Pappas et al., 2009). Populist majoritarianism is potentially incompatible with policy expertise: in the case of a marked gap between popular beliefs and area-specific policy evidence, the populist stance is by definition against expert positions shaped by mainstream policy paradigms. Striking examples include the anti-vaccination stance of Italian 5 Stars Movement leaders; the anti-green attitudes of Donald Trump or the economic unorthodoxy of the Greek Syriza. The reservation of populists towards mainstream policy paradigms and traditional epistemic communities often implies unconventional policy innovations and radical, paradigmatic policy reforms.

\subsection{Procedural Features of Populist Policy Making}

The procedural dimension of our ideal type is informed by the possible incompatibility between populism and liberal democracy and its preference to the majoritarian rule-a thesis widely shared in the scholarship (Albertazzi \& Mueller, 2013; Pappas, 2014). The 'populism as political logic' approach stresses the importance of personalistic leaders and their use of "direct, unmediated, uninstitutionalized support" (Weyland, 2001, p. 14).

Populist governments tend to undermine the edifice of liberal democracy through eroding the rule of law, neutralising checks and balances and marginalising political opposition (Batory, 2016; Taggart \& Rovira Kaltwasser, 2016). Discriminatory legalism is a general pattern of leftwing and right-wing populists (Weyland, 2013), although especially valid for exclusionary populism (Müller, 2016). However, the inclusionary populist Syriza government was also heavily criticised for its legal procedural practices (governing by decrees, appointing loyal judges). The inclusionary type of populism does not necessarily undermine the institutions of liberal democracy, but tends to circumvent them: For instance, the 5 Stars Movement is strongly in favour of direct democracy. That is, although to different degrees and by different means, populists have a willingness to directly communicate with the electorate.
Populist policy making means a different relation between governing politicians and other policy actors compared to the implicit policy making ideal type of liberal democracies. While usual policy process modelling frameworks such as the advocacy coalition framework (Sabatier \& Jenkins-Smith, 1993) consider subsystemspecific policy experts as main contributors to the policy process, populist political leaders tend to be hostile towards technocratic expertise, downplaying the advisory role of epistemic communities in general, and the related supranational institutions in particular. The adversarial stance of populists against technocrats who created policy monopolies is inherent; indeed, populist and technocratic forms of political representations are two different alterations of party-based governments of liberal democracies (Caramani, 2017). An important consequence of sidelining veto-players and neglecting expert consultation is that the decision making process under populist rule fundamentally differs from that in liberal democracies along each of the temporal dimensions specified by Grzymala-Busse (2011). Thus, policy making under populist governance tends to have a significantly faster tempo and a shorter duration with frequent episodes of accelerations and an unpredictable timing.

\subsection{Populist Policy Discourses}

Discourses can play a formative role in policy change (Schmidt, 2008) and they have a particular status in populist policy making. Approaches that understand populism as a communication style (Jagers \& Walgrave, 2007) or as a discourse (Aslanidis, 2016) pinpoint that populist policy making exhibits strong discursive features. Indeed, while populism is at odds with the institutionalised process of policy making, it is particularly susceptible to apply instruments of discursive governance (Korkut et al., 2015), and uses strategic metaphors extensively to ground and legitimise policy measures.

Scholarship also suggests that populist governments use a tabloid and emotional communication style with moralising adversarial narratives and crisis frames (Moffitt, 2015) reinforcing polarisation in policy positions. While the chameleonic flexibility of populist governments can imply policy choices in line with expert policy evidences, discursively populists often have a clear anti-expertise stance (Thirkell-White, 2009).

Populist government leaders tend to use Manichean language and adversarial frames in legitimising policy decisions: The menace of dangerous immigrants was frequently invoked by both Salvini and Trump in order to promote increased securitisation and law-andorder measures. Populist discourses may portray both transnationally embedded liberal groups and socially marginalised unpopular minorities as enemies of the 'real people' (Müller, 2016) thus forging social polarisation. Arguments against liberalism are discursively linked to attacks against liberal 'censorship' and reveal the potentially subversive character of populism: popular be- 
liefs have a higher moral stance than the values promulgated by elites.

Table 2 summarises the main features of the populist policy making ideal type. In the next section we qualitatively assess the conformity of an assumed typical case of populist policy making, post-2010 Hungarian social policy, with this ideal type.

\section{Applying the Ideal Type: Social Policy Reforms in Post-2010 Hungary}

Ruling since 2010, the government of Hungary under the leadership of Prime Minister Viktor Orbán has been the first clear populist administration of an EU member state that has, at the same time, moved away from liberal democracy. The governing party Fidesz has already spent a decade in power that allowed its policies to crystallise. These features make the Hungarian case especially suitable for illustrating the ideal type of populist policy making. As an attempt to apply our theoretical framework in empirical research we qualitatively assess the conformity of major social policy changes in Hungary between 2010 and 2018 to the populist policy making ideal type. Four policy areas of welfare reforms are scrutinised: pensions, taxation, unemployment programmes and family policies. We follow the logic of our ideal type construct and disentangle the content, the procedures and the discourses of social policy making.

\subsection{Policy Content}

Post-2010 Hungarian social policy reforms mainly constituted paradigmatic changes in substantive terms. Most reforms promoted 'working families' as the radical decrease of the highest personal income tax rate from $28 \%$ to $16 \%$ and the adoption of generous, family-based taxallowance system in 2011 illustrates. These changes especially benefited high-income large families, Fidesz's core electorate at the time (Szikra, 2018). Adopting a flat personal income tax system was a major shift away from the progressive taxation of the previous decades.

Paradigmatic pension reforms between 2010 and 2012 included the nationalisation of the assets of private pension funds, comprising approximately $10 \%$ of the
GDP. Disability pensioners were, at the same time, excluded from the public pension system and early retirement opportunities were stopped (Szikra \& Kiss, 2017). Women, however, were allowed to retire earlier if they had 40 years of service to care for grandchildren. This change innovatively linked pension reform to pro-natalist aims in the hope to foster childbearing with the help of grandmothers' care. Judges and public employees were, at the same time, forced to retire earlier thus older civil servants and judges were replaced by younger, loyal state employees-a measure later copied by the Polish Law and Justice party. Overall, pension reforms under Orbán exhibited radical and paradigmatic changes accompanied by innovative policy elements that oftenserved political aims beyond those strictly pertaining to pension policy.

Similarly, radical reforms featured employment policies under Orbán as the maximum length of unemployment benefit was decreased from nine to three months in 2011, resulting in the shortest unemployment benefit period within the EU (Scharle \& Szikra, 2015). The amount of social assistance benefit was nominally cut in the harshest years of the global crisis. The cabinet replaced labour market policies with a compulsory public works programme (Vidra, 2018) the administration of which was moved to the Ministry of Interior, signalling the aim to control the poor. The magnitude of the new Hungarian public works programme was "unrivalled in Europe" (Kálmán, 2015, p. 58).

These radical reforms ran against mainstream expertise. Policy experts have warned that the generous family allowances to upper-middle class families would unlikely to have any profound demographic effect but would further increase social inequalities and the adopted public works programme form was unfit to help labour market reintegration (Molnár, Bazsalya, Bódis, \& Kálmán, 2019). The forced early retirement of judges was finally overruled by the European Court of Human Rights. However, some of these policies met general public support and even the most controversial social policy measure, the public works programme, became widely accepted among the lower classes as it provided somewhat better living conditions and a new form of local integration to the unemployed, especially after 2014 (Keller,

Table 2. Ideal type of populist policy making.

Policy content Ideologically multifaceted and diverse

Heterodox policy elements with frequent policy innovations challenging mainstream policy paradigms Reflecting majoritarian preferences, hostility against unpopular minorities Radical and paradigmatic policy reforms

Policy process Circumventing established institutions, downplaying veto players

Limiting participation of technocratic policy experts, opposition parties and civil society actors

Direct communication with the electorate

Policy discourse Extensive use of discursive governance

Tabloid, highly emotional communication style, recurrent crisis framing

Dominance of Manichean discourses 
Kovács, Rácz, Swain, \& Váradi, 2016). The economic recovery after 2010 also helped the government through raising incomes and creating new jobs that counterbalanced and mitigated the effects of the shrinking social allowances. At the same time social policy changes had a polarising effect as they reinforced the sharp division between the working and non-working population. This increasing social divide seems to have resonated with the majoritarian prejudices against the sizeable Roma minority in Hungary (Tremlett, Messing, \& Kóczé, 2017).

Despite its seemingly uniform work- and familyorientation, the social policy reforms after 2010 were ideologically diverse: they entailed neo-liberal, (neo)conservative and étatist elements alike (Szikra, 2014). The abolition of progressive personal income taxation and the adoption of a flat tax was a typical neo-liberal measure that spread around Eastern Europe earlier (Appel \& Orenstein, 2013). The same can be said about the ceased early retirement possibilities. The nationalisation of private pension funds and the Women 40 programme, however, were strikingly étatist reforms. (Neo)conservativism can be traced especially in the pre-occupation of Fidesz with the traditional family ideal and the vision of a 'Christian-national' culture that was fostered by handing over an increasing number of schools and kindergartens to the church. Our findings about the heterodox policy content welfare reforms confirm the understanding of Körösényi and Patkós (2017) who, borrowing the term of Carstensen (2011), labelled Orbán a bricoleur innovatively blending ideas from different paradigms.

Overall, the content of Hungarian social policy reforms after 2010 shows a high degree of conformity with the populist ideal type. First, it is impossible to identify one specific underlying ideology of its measures as they represent a blend of neo-liberal, conservative and étatist approaches. Second, most measures imply radical and paradigmatic policy reforms, in stark contrast with the general wisdom of incremental policy change. Third, measures are often policy innovations challenging mainstream policy paradigms and expert consensus.

\subsection{Policy Making Procedures}

All the way through its social policy reforms, the Orbán cabinets negated institutionalised consultation and consensus-seeking. The supermajority of Fidesz in Parliament created an appropriate environment for the unilateral adoption of legislation in various policy fields and it provided the opportunity to substantially redesign the institutional context of policy making. The main institution of social dialogue, the tripartite consultation body involving trade unions and employers' organisations was replaced by a new consultative forum that has no veto power in the policy process and acts only as an advisory board to the government. Another important veto player, the formerly influential Constitutional Court was sidelined by abolishing its right to overrule economic and social-policy-related legislation. As a means to by-pass normal parliamentary procedures, such as debates in parliamentary committees and thus speed up the legislative process the method of individual motion to present bills was frequently used, including the case of the enactment of the new Constitution. The legislative style of Fidesz effectively limited the possibility of the opposition to influence the decision making. Between 2010 and 2014 not one bill or legislative amendment proposed by the opposition parties was upheld by the parliamentary majority, which is unprecedented in the history of Hungarian democracy since 1990 (Boda \& Patkós, 2018).

The above procedural features clearly exhibit antiinstitutional attitudes and voluntarist style of decision making limiting the participation of policy actors. Still, the outcomes of policy changes were institutionalised into legislation with the help of the governmental majority in the parliament and the disciplined Fidesz parliamentary group that upholds all governmental initiatives. That is, the social policy making procedures of the Orbán governments represent a somewhat paradoxical anti-institutionalism.

Meanwhile, intermediary consultative institutions were replaced by direct communication with the people via so-called 'national consultation.' Questionnaires were repeatedly sent to all Hungarian households enquiring, among others, about social policy issues, like social assistance for the non-working or the demographic problems of the country. The government justified its position on policy issues with a reference to the majoritarian opinion expressed through the national consultations. As Batory and Svensson (2019, p. 239) argue national consultations "come to replace 'ordinary' policy-making and accountability mechanisms" under Orbán. Between 2010 and 2018 eight national consultations were organised, out of which five included questions about social policy issues. The last one focused exclusively on family policy. Each national consultation was accompanied by extensive communication campaigns in the media and on billboards portraying the government as listening to the voice of people.

As an important procedural feature, the peculiar timing and tempo of reforms (Grzymala-Busse, 2011) also fits the predictions of the populist ideal type. The government issued major changes simultaneously especially at the beginning of its terms and carried changes out at extreme speed. For instance, the nationalisation of private pension fund assets and the adoption of the new Fundamental Law were adopted within just a few months. As reform plans were not revealed in the electoral programme of Fidesz (apart from a flat rate personal income tax), stakeholders were unable to organise and react. The emergency character of Central and Eastern European welfare states is a historical feature (Inglot, 2008) but the global economic downturn and the internal political situation provided a context where such emergency decisions were more easily legitimised.

Summarising the above points: The procedural features of Hungarian policy making after 2010 correspond 
to most elements of the populist ideal type. It is characterised by a marked anti-institutionalism concerning the role of veto players, pluralism and participation. These features in turn resulted in an accelerated pace of legislation. Fidesz has made extensive use of 'national consultations' as means of direct communication with the people in order to legitimise its decisions. However, we pointed out a paradoxical anti-institutionalism that refers only to the process of policy making, not to the outcomes that were formalised in legislation.

\subsection{Policy Discourses}

Since Fidesz has had a comfortable majority in the parliament it could easily legislate, which also means that the Orbán governments did not have to rely on discursive governance in the sense of initiating policy change without institutional/legislative change (Korkut \& Eslen-Ziya, 2016). Still, major social policy reforms were often accompanied by campaigns using a highly emotional crisis communication depicting varying 'enemies' of Hungarians. The government and the prime minister personally were repeatedly positioned as the saviours of the nation. During the renationalisation of private pension funds in 2010-2012, multinational banks and insurance companies were accused for 'gambling' with people's money and thus the prime minister appointed a Commissioner for the Protection of Pensions to 'save' the pensions of Hungarians (Aczél, Szelewa, \& Szikra, 2014). That is, while the government was nationalising people's private pension savings, the discursive frame was about 'protecting' the pensions against the gambling of private funds; and this frame was used even in the denomination of a formal governmental position.

Fidesz framed social policy changes in a European context and pictured Hungary as being the leader (as opposed to a follower or even latecomer) of the transformation of the European social agenda. In this narrative Western welfare states were portrayed as being in decline and 'work-based society' (munka alapú társadalom) was offered as a counter-narrative. Viktor Orbán declared that the goal of the government was to achieve full employment and people were expected to work, and that no benefits would be handed out to the nonworking. Those who do not find employment on the labour market have to enrol in the public works programme. The frame of 'work-based society' has not only been a recurrent theme in the speeches of the Prime Minister but has been also offered as a legitimising idea in several policy fields where benefits were linked to being employed. For instance, while the amount of the universal child allowance has not been increased for a decade resulting in a serious loss of its purchasing power, the government introduced generous income tax cuts for parents with several children-a benefit targeting those who work and have legal revenue. According to the wording of the 2011 Cardinal Act on the Protection of Families, the support of families was defined as being "distinct from the system of social provision for the needy" (Szikra, 2019 , p. 234). In the Hungarian context, this terminology suggested that the unemployed, the poor and among them many of the Roma families were excluded from the focus of family policies that aimed to "boost the fertility of the middle class" (Szikra, 2019, p. 234)-an objective that a policy article of the government explicitly set (Rat \& Szikra, 2018; Szikra, 2019).

Since the spring of 2015, however, the rhetoric of Fidesz shifted from the 'hard working' to 'migration crises.' In its sweeping media campaigns, the government portrayed migrants and refugees as posing a direct threat to the security and well-being of all Hungarians (Messing \& Bernáth, 2017). In this context, family policy with a focus on fertility rates was put in a sharp opposition with immigration from Islamic countries. Accordingly, related questions were posed to the public in the 2015 national consultation on 'immigration and terrorism' and in 2018 on the 'protection of families' (Batory \& Svensson, 2019). National consultations, as well as repeated speeches of the Prime Minister, explicitly linked the issue of immigration to the problem of low fertility: "Do you agree with the government that instead of allocating funds to immigration we should support Hungarian families and those children yet to be born?" and "Brussels wants to force Hungary to let in illegal immigrants" (Batory \& Svensson, 2019, p. 4). This powerful frame related 'Brussels' to 'immigration'; and 'immigration' was contrasted with 'the support to families.' This way Hungarian families were put into opposition with both 'Brussels' and 'immigration.'

Since 2016, the campaign against György Soros and the Central European University was linked to a narrative about another new enemy, that of 'gender ideology.' Similarly to conservative right-wing movements in Europe and the US, high-ranking Fidesz-politicians used a tabloid and highly emotional communication style about 'gender craziness' that ran against the 'natural' instincts of men and women (Kováts \& Põim, 2015). The protection of the traditional family through novel family policy programmes in the frame of 'demographic governance' was offered as a solution against such horrors.

To sum up, since 2010 extensive communication campaigns accompanied government decisions, including several social policy reforms. The government's communication exhibits features of populist style using highly emotional frames, adversarial narratives, depiction of crises and enemies, and expressing a Manichean logic opposing the Hungarian society to external enemies, and creating a sharp distinction between the 'worthy' and the 'unworthy' parts of the society.

\subsection{Congruence Analysis}

As put forth in Section 2 of the article, our aim with the empirical overview of post-2010 Hungarian social policy is to provide insights into how populist policies could be analysed by disentangling the three constitutive dimen- 
Table 3. Assessing the conformity of post-2010 Hungarian social policy with the ideal type of populist policy making.

\begin{tabular}{|c|c|c|}
\hline \multirow[t]{4}{*}{ Policy content } & Ideologically multifaceted and diverse & ++ \\
\hline & $\begin{array}{l}\text { Heterodox policy elements with frequent policy innovations challenging mainstream } \\
\text { policy paradigms }\end{array}$ & ++ \\
\hline & Reflecting majoritarian preferences, hostility against unpopular minorities & ++ \\
\hline & Radical and paradigmatic policy reforms & ++ \\
\hline \multirow[t]{3}{*}{ Policy process } & Circumventing established institutions, downplaying veto players & $-/+$ \\
\hline & Limiting participation of technocratic policy experts, opposition parties and civil society actors & ++ \\
\hline & Direct communication with the electorate & ++ \\
\hline \multirow[t]{3}{*}{ Policy discourse } & Extensive use of discursive governance & + \\
\hline & Tabloid, highly emotional communication style, recurrent crisis framing & ++ \\
\hline & Dominance of Manichean discourses & ++ \\
\hline
\end{tabular}

Notes: '++': high conformity; '+': moderate conformity; '-': disconformity; '-/+': inconclusive findings.

sions of the populist policy making ideal type. Table 3 offers the result of the congruence analysis we performed, assessing the conformity of post-2010 Hungarian social policy with the ideal type of populist policy making. The congruence analysis was made in qualitative terms: We weighed whether, and if so, how much, are the typical features of the major policy reforms in conformity with the elements of the model.

Table 3 shows that Hungarian social policy under Fidesz government strongly conformed to the populist ideal type in all three dimensions (content, procedure and discourse). Some features are less accentuated: for instance, Fidesz has not relied extensively on discursive governance as it has had the legislative power to enact policies. An ambiguous point is institutionalisation because Orbán's social policy, while largely circumventing institutional consultation mechanisms, led to a strong institutionalisation by 2018 , with various social policy fields enacted in the constitution or in cardinal acts.

\section{Conclusions}

Populist parties have increasingly gained power in Europe and beyond offering a novel opportunity to study the way they govern. The main aim of this article was to conceptualise policy making features of populist governments. As a point of theoretical departure, we reconstructed the implicit ideal type of policy making in liberal democracies where a plurality of actors participates in the policy process that is constrained by formal and informal institutions and competing policy discourses shape policy alternatives. This policy making ideal type generally applies in liberal democracies independently from the functionalist model of governance in a broader sense.

Then, reviewing the populism scholarship, we constructed an ideal type of populist policy making. The content of populist policies is partly shaped by the underlying core ideologies; still, policy heterodoxy, strong willingness to adopt paradigmatic reforms and an excessive responsiveness to majoritarian preferences are probably distinguishing features of any type of populist policies.
Discursively, populist political leaders tend to use crisis frames and discursive governance instruments such as strategic metaphors in a Manichean language to legitimise policy decisions. Direct communication with the electorate and circumvention of existing institutions is a general pattern of populist policy making, but more inclusionary variants of populist governance tend to respect the established democratic procedures more.

In addition to the primarily theoretical ambitions of this research we attempted to use our ideal type in empirical investigation. We selected an assumed typical case of populist policy making, social policy in post2010 Hungary for the congruence analysis. Our qualitative assessment suggests a high degree of conformity between the ideal type of populist policy making and the selected case. Orbán's social policy reforms were paradigmatic but featured diverse ideological directions. The process of policy making circumvented conventional institutionalised policy mechanisms and was extraordinarily speedy. Unmediated consultations with the people and adversarial, polarising narratives accompanied social policy reforms; features that are rarely present in policy making in liberal democracies.

Understanding populist policy making has important theoretical and practical policy implications. First and foremost, it helps us explain how and why populists survive in power even in the longer run. Reasons for success of populist governance might include the ideological flexibility that closely follows majoritarian preferences of the electorate. Our findings also confirm the ambiguous relationship between populist governance and liberal democracy. While majoritarian preferences may legitimise populist policy reforms, abrupt and radical policy changes downplay institutional and policy expertise control mechanisms and are routinely supported by adversarial narratives. On the one hand, these features tend to undermine the institutions of liberal democracy; on the other hand, they inevitably foster social and political polarisation. This is particularly harmful for unpopular minorities, including the poor, the Roma, migrants and LGBTQ communities, who can easily become the scapegoats and the losers of policy changes. Given the proce- 
dural features of populism, social groups with weak lobbying power might easily become excluded from decision making and their voices remain unheard. This process leads to the decline of participatory democracy and decreases the quality of policy making.

Our study has its limitations. First, our empirical exercise serves illustrative purposes and it does not provide a rigorous case study in adopting the theoretical construct. Second, while we had the theoretical ambition of constructing a general ideal type of populist policy making, we assessed the congruence of it only with a right-wing populist case. Further research may justify the relevance of populist policy making in empirical analysis and clarify the extent to which this ideal type needs adjustment to capture the main features of populist policy making in varying ideational contexts.

\section{Acknowledgments}

This research has received funding from the National Research, Development and Innovation Fund of Hungary (project no. K129245) as well as the European Union's Horizon 2020 research and innovation programme under grant agreement No. 822590. Any dissemination of results here presented reflects only the authors' view. The Agency is not responsible for any use that may be made of the information it contains. Earlier versions of this article have been discussed at the 4th Prague Populism Conference in 2018 and the ESPAnet Annual Conference, 2019, Stockholm. The authors express their gratitude to the anonymous reviewers as well as to Umut Korkut, András Körösényi and the researchers of the Department of Governance and Public Policy at the Centre for Social Sciences whose comments greatly improved the manuscript. They thank Christiaan Swart for the English editing of the text.

\section{Conflict of Interests}

The authors declare no conflict of interests.

\section{References}

Aczél, Z., Szelewa, D., \& Szikra, D. (2014). The changing language of social policy in Hungary and Poland. In K. Petersen \& D. Béland (Eds.), Analysing social policy concepts and language: Comparative and transnational perspectives (pp. 35-57). Bristol: Policy Press.

Albertazzi, D., \& Mueller, S. (2013). Populism and liberal democracy: Populists in government in Austria, Italy, Poland and Switzerland. Government and Opposition, 48(3), 343-371.

Appel, H., \& Orenstein, M. A. (2013). Ideas versus resources: Explaining the flat tax and pension privatization revolutions in Eastern Europe and the former Soviet Union. Comparative Political Studies, 46(2), 123-152.

Aslanidis, P. (2016). Is populism an ideology? A refuta- tion and a new perspective. Political Studies, 64(1), 88-104.

Bartha, A. (2017). Makrogazdasági stabilizáció másképp: a gazdaságpolitika populista fordulata [An alternative way of macroeconomic adjustment: the populist turn]. In Z. Boda \& A. Szabó (Eds.), Trendek a magyar politikában 2: A Fidesz és a többiek: pártok, mozgalmak, politikák [Trends in Hungarian Politics 2: Fidesz and the others: Parties, movements and policies] (pp. 311-343). Budapest: Napvilág Kiadó.

Batory, A. (2016). Populists in government? Hungary's "system of national cooperation." Democratization, 23(2), 283-303.

Batory, A., \& Svensson, S. (2019). The use and abuse of participatory governance by populist governments. Policy \& Politics, 47(2), 227-244.

Baumgartner, F. R., Berry, J. M., Hojnacki, M., Leech, B. L., \& Kimball, D. C. (2009). Lobbying and policy change: Who wins, who loses, and why. Chicago, IL: University of Chicago Press.

Béland, D. (2009). Ideas, institutions, and policy change. Journal of European Public Policy, 16(5), 701-718.

Blatter, J., \& Haverland, M. (2012). Designing case studies: Explanatory approaches in small-N research. London: Palgrave Macmillan.

Boda, Z., \& Patkós, V. (2018). Driven by politics: Agenda setting and policy-making in Hungary 2010-2014. Policy Studies, 39(4), 402-421.

Boda, Z., \& Sebők, M. (2019). The Hungarian policy agendas project. In F. Baumgartner, C. Breuning, \& E. Grossman (Eds.), Comparative policy agendas: Theory, tools, data (pp. 105-113). Oxford: Oxford University Press.

Canovan, M. (1999). Trust the people! Populism and the two faces of democracy. Political Studies, 47(1), 2-16.

Caramani, D. (2017). Will vs. reason: The populist and technocratic forms of political representation and their critique to party government. American Political Science Review, 111(1), 54-67.

Carstensen, M. B. (2011). Paradigm man vs. the bricoleur: Bricolage as an alternative vision of agency in ideational change. European Political Science Review, 3(1), 147-167.

Cox, R. H., \& Béland, D. (2013). Valence, policy ideas, and the rise of sustainability. Governance, 26(2), 307-328.

De Cleen, B. (2017). Populism and nationalism. In C. Rovira Kaltwasser, P. Taggart, P. Ochoa Espejo, \& P. Ostiguy (Eds.), The Oxford handbook of populism (pp. 342-362). Oxford: Oxford University Press.

Grzymala-Busse, A. (2011). Time will tell? Temporality and the analysis of causal mechanisms and processes. Comparative Political Studies, 44(9), 1267-1297.

Hawkins, K., \& Littvay, L. (2019). Contemporary US populism in comparative perspective. Cambridge: Cambridge University Press.

Inglot, T. (2008). Welfare states in East Central Europe, 
1919-2004. Cambridge: Cambridge University Press. Jagers, J., \& Walgrave, S. (2007). Populism as political communication style: An empirical study of political parties' discourse in Belgium. European Journal of Political Research, 46(3), 319-345.

Jenne, E. K., \& Mudde, C. (2012). Hungary's illiberal turn: Can outsiders help? Journal of Democracy, 23(3), 147-155.

Kálmán, J. (2015). The background and the international experiences of public works programmes. In K. Fazekas \& J. Varga (Eds.), The Hungarian labour market, 2015 (pp. 42-58). Budapest: Institute of Economics of Hungarian Academy of Sciences.

Keller, J., Kovács, K., Rácz, K., Swain, N., \& Váradi, M. (2016). Workfare schemes as a tool for preventing the further impoverishment of the rural poor. Eastern European Countryside, 22(1), 5-26.

Ketola, M., \& Nordensvard, J. (2018). Reviewing the relationship between social policy and the contemporary populist radical right: Welfare chauvinism, welfare nation state and social citizenship. Journal of International and Comparative Social Policy, 34(3), 172-187.

Knight, A. (1998). Populism and neo-populism in Latin America, especially Mexico. Journal of Latin American Studies, 30(2), 223-248.

Korkut, U., \& Eslen-Ziya, H. (2011). The impact of conservative discourse in family policies: Population politics and gender rights in Poland and Turkey. Social Politics, 18(3), 387-418.

Korkut, U., \& Eslen-Ziya, H. (2016). The discursive governance of population politics: The evolution of a probirth regime in Turkey. Social Politics: International Studies in Gender, State \& Society, 23(4), 555-575.

Korkut, U., Mahendran, K., Bucken-Knapp, G., \& Cox, R. H. (2015). Introduction. Discursive governance: Operationalization and applications. In U. Korkut, K. Mahendran, G. Bucken-Knapp, \& R. H. Cox (Eds.), Discursive governance in politics, policy, and the public sphere (pp. 1-11). New York, NY: Palgrave Macmillan.

Körösényi, A., \& Patkós, V. (2017). Variations for inspirational leadership: The incumbency of Berlusconi and Orbán. Parliamentary Affairs, 70(3), 611-632.

Kováts, E., \& Põim, M. (Eds.). (2015). Gender as symbolic glue: The position and role of conservative and far right parties in the anti-gender mobilizations in Europe. Budapest: Friedrich Ebert Stiftung.

Kriesi, H. (2014). The populist challenge. West European Politics, 37(2), 361-378.

Messing, V., \& Bernáth, G. (2017). Disempowered by the media: Causes and consequences of the lack of media voice of Roma communities. Identities, 24(6), 650-667.

Moffitt, B. (2015). How to perform crisis: A model for understanding the key role of crisis in contemporary populism. Government and Opposition, 50(2), 189-217.

Molnár, G., Bazsalya, B., Bódis, L., \& Kálmán, J. (2019). Public works in Hungary: Actors, allocation mecha- nisms and labour mobility effects. Social Science Review, 7, 117-142.

Morgan, K. J. (2013). Path shifting of the welfare state: Electoral competition and the expansion of workfamily policies in Western Europe. World Politics, 65(1), 73-115.

Mudde, C. (2004). The populist zeitgeist. Government and Opposition, 39(4), 541-563.

Mudde, C., \& Rovira Kaltwasser, C. (2012). Populism and (liberal) democracy: A framework for analysis. In C. Mudde \& C. Rovira Kaltwasser (Eds.), Populism in Europe and the Americas: Threat or corrective for democracy? (pp. 1-26). New York, NY: Cambridge University Press.

Müller, J. W. (2016). What is populism? Philadelphia, PA: University of Pennsylvania Press.

O'Malley, E., \& FitzGibbon, J. (2015). Everywhere and nowhere: Populism and the puzzling non-reaction to Ireland's crises. In H. Kriesi \& T. S. Pappas (Eds.), European populism in the shadow of the great recession (pp. 287-302). Colchester: ECPR Press.

Pappas, C., Mendez, J., \& Herrick, R. (2009). The negative effects of populism on gay and lesbian rights. Social Science Quarterly, 90(1), 150-163.

Pappas, T. S. (2014). Populist democracies: Postauthoritarian Greece and Post-communist Hungary. Government and Opposition, 49(1), 1-23.

Peters, B. G., \& Pierre, J. (2016). Comparative governance: Rediscovering the functional dimension of governing. Cambridge: Cambridge University Press.

Przeworski, A., Stokes, S. C. S., Stokes, S. C., \& Manin, B. (Eds.). (1999). Democracy, accountability, and representation (Vol. 2). Cambridge: Cambridge University Press.

Raț, C., \& Szikra, D. (2018). Family policies and social inequalities in Central and Eastern Europe: A comparative analysis of Hungary, Poland and Romania between 2005 and 2015. In G. B. Eydal \& T. Rostgaard (Eds.), Handbook of child and family policy (pp. 223-236). Cheltenham: Edward Elgar Publishing.

Rosenberg, M. M. (2016). The conceptual articulation of the reality of Life: Max Weber's theoretical constitution of sociological ideal types. Journal of Classical Sociology, 16(1), 84-101.

Sabatier, P. A., \& Jenkins-Smith, H. C. (1993). Policy change and learning: An advocacy coalition approach. Boulder, CO: Westview Press.

Scharle, Á., \& Szikra, D. (2015). Recent changes moving Hungary away from the European social model. In D. Vaughan-Whitehead (Ed.), The European social model in crisis: Is Europe losing its soul? (pp. 229-261). Cheltenham: Edward Elgar Publishing.

Schmidt, V. A. (2008). Discursive institutionalism: The explanatory power of ideas and discourse. Annual Review of Political Science, 11, 303-326.

Stavrakakis, Y., \& Katsambekis, G. (2014). Left-wing populism in the European periphery: The case of SYRIZA. Journal of Political Ideologies, 19(2), 119-142. 
Szikra, D. (2014). Democracy and welfare in hard times: The social policy of the Orbán Government in Hungary between 2010 and 2014. Journal of European Social Policy, 24(5), 486-500.

Szikra, D. (2018). Welfare for the wealthy: The social policy of the Orbán-regime, 2010-2017. Budapest: Friedrich Ebert Stiftung.

Szikra, D. (2019). Ideology or pragmatism? Interpreting social policy change under the 'system of national cooperation' In J. M. Kovács \& B. Trencsényi (Eds.), Brave new Hungary: Mapping the 'system of national cooperation' (pp. 225-241). Lanham, MA: Rowman and Littlefield.

Szikra, D., \& Kiss, D. (2017). Beyond nationalization: Assessing the impact of the 2010-2013 pension reform in Hungary. Review of Sociology, 27(4), 83-107.

Taggart, P. (2004). Populism and representative politics in contemporary Europe. Journal of Political Ideologies, 9(3), 269-288.

Taggart, P., \& Rovira Kaltwasser, C. (2016). Dealing with populists in government: Some comparative conclusions. Democratization, 23(2), 345-365.

Thirkell-White, B. (2009). Dealing with the banks: Populism and the public interest in the global financial crisis. International Affairs, 85(4), 689-711.

Tremlett, A., Messing, V., \& Kóczé, A. (2017). Romaphobia and the media: Mechanisms of power and the politics of representations. Identities, 24(6), 641-649.

Urbinati, N. (2017). Populism and the principle of majority. In C. Rovira Kaltwasser, P. Taggart, P. Ochoa Espejo, \& P. Ostiguy (Eds.), The Oxford handbook of populism (pp. 571-589). Oxford: Oxford University Press.

Vidra, Z. (2018). Hungary's punitive turn: The shift from welfare to workfare. Communist and PostCommunist Studies, 51(1), 73-80.

Weible, C. M. (2008). Expert-based information and policy subsystems: A review and synthesis. Policy Studies Journal, 36(4), 615-635.

Weyland, K. (2001). Clarifying a contested concept: Populism in the study of Latin American politics. Comparative Politics, 34(1), 1-22.

Weyland, K. (2013). Latin America's authoritarian drift: The threat from the populist left. Journal of Democracy, 24(3), 18-32.

Wodak, R. (2015). The politics of fear: What right-wing populist discourses means. London: SAGE.

\section{About the Authors}

Attila Bartha (PhD) is a Research Fellow at the Institute for Political Science of the Centre for Social Sciences and an Associate Professor at the Department of Public Policy, Institute for Economic and Public Policy, Corvinus University of Budapest. Since 2015 he has been a Founding Editor of the journal Intersections: East European Journal of Society and Politics. His main areas of research are comparative public policy, welfare policy and political economy.

Zsolt Boda (PhD) is Research Chair and Director General of the Centre for Social Sciences, Budapest and Associate Professor at the Law Faculty of the ELTE University, Budapest. He is a Political Scientist working in policy studies and trust research. Currently he is the Coordinator of 'DEMOS: Democratic Efficacy and the Varieties of Populism in Europe,' an H2020 consortial research project (2019-2021) involving 15 academic institutions across Europe.

Dorottya Szikra (PhD habil.) is Head of Research Department and Senior Researcher at the Institute for Sociology, Center for Social Sciences, Budapest, and Visiting Professor at the Department of Gender Studies, Central European University Budapest-Vienna. Her main research field is welfare state development in Central and Eastern Europe. Between 2016 and 2020 she acted as the Co-Chair of the European Social Policy Analysis Network (ESPAnet). 